\title{
Staying in competition
}

\section{Washington}

If the United States is to retain its competitive edge in the international biotechnology arena, federal regulators must reduce the burden of regulations that hamper companies trying to bring products to market. That is the conclusion of a Report on National Biotechnology Policy released last week by the President's Council on Competitiveness.

The report also played down the risks of bioengineered organisms, stating that "products developed through biotechnology processes do not per se pose risks to human health and the environment".

Thus the council continues to oppose efforts to introduce new legislation to regulate biotechnology - a position that is in concurrence with the 1986 Coordinated Framework for the Regulation of Biotechnology, which was a guide for federal agencies with overview for biotechnology to follow. When evaluating an organism, the report says, federal regulators should disregard whether it has been produced by traditional breeding methods or recombinant DNA techniques and instead focus on the individual characteristics of the organism and its intended use.

Although most scientists would probably find this a reasonable position, it does bother some critics. Margaret Mellon, director of the National Wildlife Federation, called the report the administration's "most extreme statement yet" of its "unwillingness to regulate the technology". Mellon's organization supports the introduction of new legislation to establish a comprehensive regulatory framework for environmental release. She argues that neither the interests of the public nor of industry are best served by issuing a "blanket reassurance" that the technology is safe and by attempting "to force the whole technology" upon the consumer — which she says is happening with recombinant bovine somatotropin.

Among the report's 15 recommendations, the administration continues to oppose any legislative changes to the Orphan Drug Act that would, undermine the economic incentives - tax incentives and marketing advantages - provided to companies that develop drugs to treat rare diseases (defined as those affecting fewer than 200,000 people). Although most agree that the act has worked well for the most part, critics argue that in a few cases the market monopoly has had the unintended effect of allowing companies to reap huge profits for drugs that would probably have been developed without the incentives of the act. Last year, Congress attempted to amend the act to allow limited competition in cases where a drug is expected to be so profitable that two or more companies are in a race to market it, but the effort was thwarted when President George Bush would not sign the amendments into law.

The Council on Competitiveness also recommended that the US should pay attention to safeguarding intellectual property rights in biotechnology, in particular by bringing US patent law more in line with that of Europe and Japan. The administration says it would back legislation authorizing the US Patent Office to grant patent protection for the production process, so long as the starting material is novel; this would close what many believe to be a loophole in US patent law. It is expected that legislation addressing these problems, introduced last year by Rep- resentative Rick Boucher (Democrat, Virginia), will be reintroduced this year.

Pamela Bridgen, executive director of the Association of Biotechnology Companies, says that the council's intention to re-examine tax issues could have a beneficial effect on small biotechnology companies, particularly those that are not yet profitable. As the tax rules stand at present, "the research and experimentation tax credit is of no value to small companies", says Bridgen.

Almost five years have lapsed since the Coordinated Framework was published, and both the Environmental Protection Agency and the US Department of Agriculture have still to put in place the regulations that will be necessary to guide products through to commercialization.

Diane Gershon ENERGY POLICY

\section{More free market, less regulation, Bush asks}

\section{Washington}

With the unveiling of his National Energy Strategy last week, President George Bush threw his weight firmly behind a free market approach to energy policy. He called for decreasing the country's demand for oil, increasing US production of oil and expanding the use of alternative fuels - all with as little direct government intervention as possible.

Prominent in the proposal was an appeal for research and development aimed at fostering new sources of energy, including safer atomic power and nuclear fusion. "Investing in American ingenuity and know-how is a far better way of achieving our energy objectives than relying on command and control measures, such as increased government regulations and taxes", said the Department of Energy in a prepared statement.

To reverse the US trend away from nuclear power, Bush is urging regulatory reform to make it easier to license nuclear reactors, and is pushing for the establishment of a nuclear waste repository - an act that so far has been delayed by squabbling over where the waste storage site will be located. And to guarantee that nuclear energy can continue to supply at least 20 per cent of US energy needs over the next several decades, the president's strategy asks for accelerated development of advanced reactors.

As part of a long-term plan to achieve a stable energy supply, the policy points to fusion power and sets the goals of an operating demonstration plant by 2025 and commercial fusion power by 2040 . This emphasis heartened fusion enthusiasts, who have often seen their funding cut and their timetables delayed. But the energy document has one major weakness, said Steve Dean, president of Fusion Power Associates, an industry association in
Rockville, Maryland: "It doesn't talk about how much should be spent, or where the money will come from".

Indeed, although Bush can implement more than half of the energy strategy's 100 separate proposals without congressional approval, most of its more important elements must be put into effect by Congress, and the president will face a fight on many of them.

Perhaps the most difficult sections of the plan to get through Congress deal with the supply of and demand for petroleum. Bush foresees decreasing US oil demand by $\mathbf{3 . 4}$ million barrels a day by 2010 while increasing domestic supply by 3.8 million barrels a day. Much of the projected decrease in demand would be the result of improved energy efficiency in both transportation and residential, commercial and industrial energy use; the president's plan would produce this increased efficiency more from federal support for research and development than taxes and regulations aimed at conservation. In particular, Bush rejected increasing the average mileage standards that the federal government now demands from automobile manufacturers.

To increase US oil production, Bush would open the Arctic National Wildlife Refuge in Northern Alaska and areas of the outer continental shelf to oil drilling. This proposal was attacked by environmental and conservation groups, such as the Natural Resources Defense Council and the Sierra Club, which called the policy a sell-out to the energy industry.

Democrats in Congress warned that the Republican president will have to compromise, saying that he is unlikely, for instance, to get approval for both drilling in the wildlife refuge and keeping the mileage standards where they are.

Robert Pool 